УДК 681.5.037

\title{
МОДЕЛИРОВАНИЕ АВТОМАТИЧЕСКОЙ СИСТЕМЫ РЕГУЛИРОВАНИЯ ТЕМПЕРАТУРЫ ПРОЦЕССА СТАБИЛИЗАЦИИ КАТАЛИЗАТА В УСЛОВИЯХ НЕОПРЕДЕЛЕННОСТИ
}

\author{
Джамбеков Азамат Матифулаевич1 \\ dzhambekovam@yandex.ru
}

\author{
Дмитриевский Борис Сергеевич2, \\ dmiboris@yandex.ru \\ 1 Астраханский государственный технический университет, \\ Россия, 414056, г. Астрахань, ул. Татищева, 16. \\ 2 Тамбовский государственный технический университет, \\ Россия, 392000, г. Тамбов, ул. Советская, 106.
}

\begin{abstract}
Актуальность работы состоит в необходимости учета влияния возмущений (изменение качества нестабильного катализата, качества топливного газа) на процесс регулирования температуры в нижней части колонны стабилизации блока стабилизации катализата установки каталитического риформинга. Температура низа стабилизационной колонны является важной характеристикой блока стабилизации катализата, показатели которого характеризуют качество функционирования всего комплекса процесса риформинга. Особенность рассматриваемого объекта управления состоит в качественной инфформации, содержащейся в входных величинах и возмущающих воздействиях, к которым относятся состояние трубчатой печи, содержание бензолообразующих в нестабильном катализате, качество нестабильного катализата, качество топливного газа. Эта информация оценивается операторами на основе опыта технологов, учитывается в виде лингвистических параметров по результатам опроса экспертов и представляется фуункциями принадлежности. Влияние возмущений предложено рассматривать через параметры передаточной функции системы регулирования на основе методов робастной устойчивости. Предполагается, что данные коэфффициенты изменяются с течением времени под влиянием возмущений. При этом важной является задача исследования робастной устойчивости при регулировании температуры.

Цель: обеспечение устойчивого режима регулирования температуры колонны стабилизации в условиях неопределенности. объект: блок стабилизации катализата установки каталитического риформинга с непрерывной регенерацией катализатора. Методы: теория каталитического риформинга, моделирование, теория автоматического управления, системный анализ, вычислительная математика.

Результаты. Поставлена и решена задача исследования устойчивости регулирования температуры колонны стабилизации в условиях неопределенности. Приведена характеристика схемы процесса стабилизации катализата. Проанализирован объект управления, переменные распределены в группы как векторы, отмечены особенности объекта управления. Исследована робастная устойчивость, приведены результаты моделирования и определен радиус устойчивости, что позволяет обеспечить устойчивый режим работы автоматической системы регулирования температуры нижней части колонны при неопределенности.
\end{abstract}

\section{Ключевые слова:}

Процесс риформинга, температура низа колонны, регулирование, передаточная функция, робастная устойчивость, номинальный полином, семейство полиномов.

\section{Введение}

В [1] выполнено моделирование автоматического системы регулирования (АСР) температуры низа стабилизационной колонны (СК), принадлежащей установке каталитического риформинга (КР), а именно блоку стабилизации катализата (БСК) [2]. Октановое число стабильного катализата (продукта БСК) характеризует качество функционирования всего комплекса процесса риформинга [3]. Для эффективного управления БСК, помимо разработки эффективных алгоритмов управления, обеспечивающих достижение экономического или иного эффекта, необходимо обеспечение устойчивого режима работы АСР технологических параметров (температуры, давления, расхода и пр.). Одним из основных параметров технологического процесса в БСК является температура нижней части колонны стабилизации [4]. На регулирование температуры низа СК оказывают влияние возмущения: изменение качества нестабильного катализата, качества топливного газа [5].
Данные возмущения необходимо учитывать при разработке АCР температуры нижней части СК [6]. В [1] коэффициенты знаменателя в передаточной функции АСР температуры низа СК постоянные. В настоящей работе предложен учет влияния возмущений путем изменения коэффициентов знаменателя в передаточной функции АСР температуры нижней части СК с использованием методов робастной устойчивости [7]. Предполагается, что данные коэффициенты изменяются под влиянием возмущений с течением времени [8]. Важной является задача исследования робастной устойчивости АСР температуры низа СК [9].

Перед описанием постановки задачи приведем краткое описание принципиальной схемы БСК и анализ процесса стабилизации как объекта управления.

\section{Описание схемы БСК}

Из блока КР нестабильный катализат переводится в теплообменник $T-1$, обогреваемый стабильным, а 
затем направляется в колонну стабилизации $C$-3 (рис. 1) [10].

В колонне $C$-3 происходит процесс стабилизации катализата, заключающийся в выводе из верхнего сечения колонны $C$-3 газа стабилизации, нестабильной головки. Далее происходит охлаждение и частичная конденсация газа стабилизации и нестабильной головки в аппарате $H-3$ и $H-4$. Сепарация газа стабилизации, а также нестабильной головки производится в E-1 [11].
Газ стабилизации переводится в топливную сеть, жидкая фаза используется для орошения верха $C-3$ [12].

Сбалансированный объем головки стабилизации выводится из емкости $E-1$ с помощью насоса $N-3$ и направляется для осуществления процессов в блоке очистки и выделения сжиженных газов [13].

В теплообменнике $T$-1 происходит теплообмен стабильного катализата, выходящего из нижней части колонны $C$-3, и нестабильного катализата. Стабильный катализат направляется для осуществления процессов в товарном блоке [14].

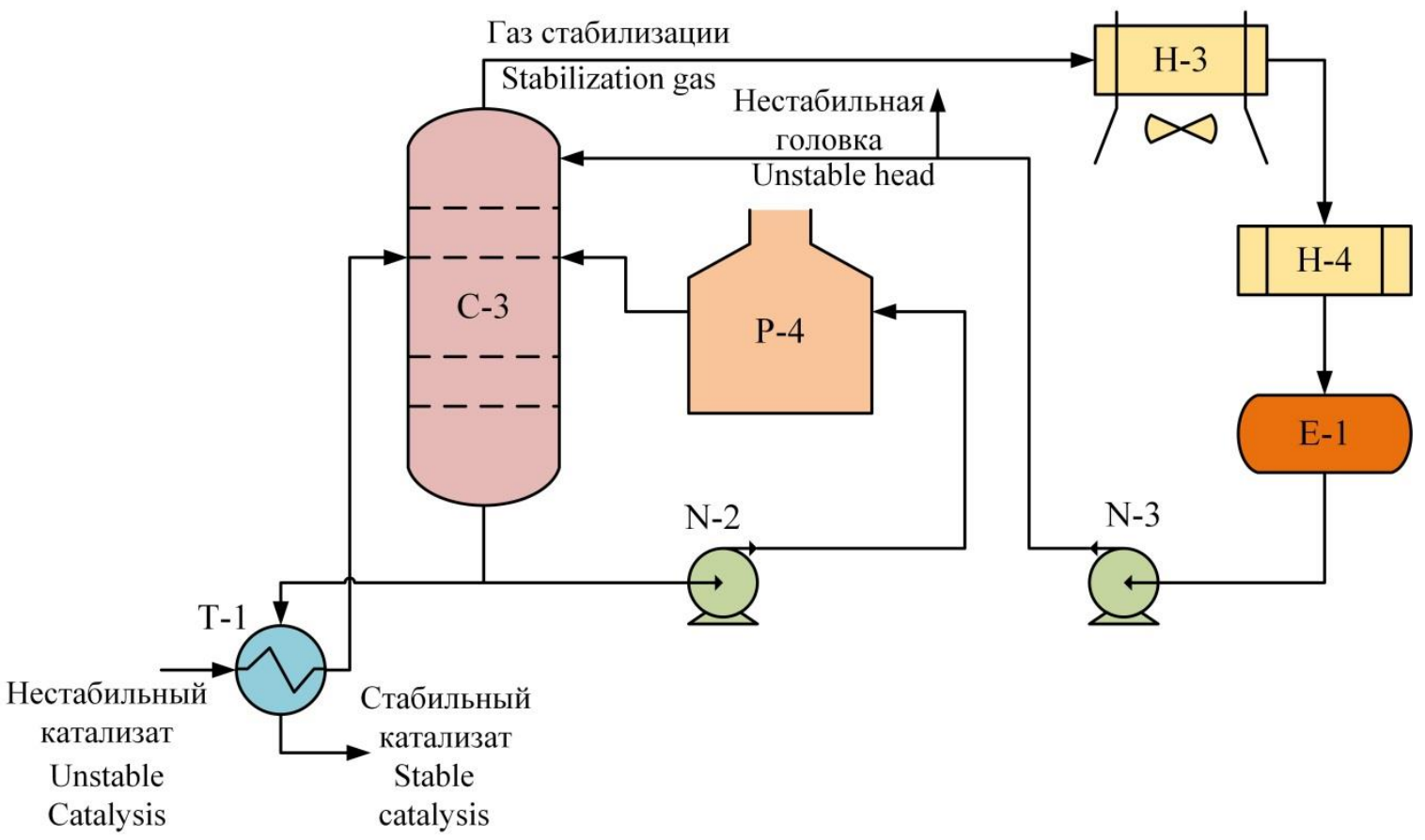

Рис. 1. Принциииальная схема процесса стабилизации

Fig. 1. Schematic diagram of stabilization

\section{Анализ процесса стабилизации как объекта управления}

Процесс стабилизации катализата характеризуется набором переменных (входных, выходных), воздействий (управляющих, возмущающих) (рис. 2) [13].

Переменные и воздействия выделены в 4 группы и представлены векторами [14]:

1. Вектор управлений $\boldsymbol{U}$ : сбрасываемый газ стабилизации (объемный расход) $Q_{g s}$; объемный расход топливного газа $Q_{f g}$; объемный расход нестабильного катализата $Q_{u c}$.

2. Вектор возмущений $\boldsymbol{V}$ : качество топливного газа $Q F G$; качество нестабильного катализата $Q U C$.

3. Вектор входов $\boldsymbol{A}$ : температура нестабильного катализата, измеряемая на входе в колонну стабилизации $T_{i n}$; коэффициент, учитывающий избыток воздуха, находящегося в печи $\alpha$; оценка состояния трубчатой печи $C T F$; оценка содержания в нестабильном катализате бензолообразующих соединений $C B F$; скорость подачи насосом нестабильного катализата $Q_{V}$.

4. Вектор выходов $\boldsymbol{W}$ : температура стабильного катализата, измеряемая на выходе из колонны ста- билизации $T_{\text {out }}$; давление в колонне $P$; перепад температуры в колонне $\Delta T$; издержки организации процесса $Z$; октановое число стабильного катализата $O N$.

Предполагаем, что выходы не изменяются, если не изменяются входы и управления [15].

Особенность объекта заключается в имеющейся в векторах входов $\boldsymbol{A}$ и возмущений $\boldsymbol{V}$ качественной информации: состояние трубчатой печи $C T F$; содержание бензолообразующих в нестабильном катализате $C B F$; качество нестабильного катализата $Q U C$; качество топливного газа $Q F G$. В [16] предложено определять данную информацию в модели КР как лингвистические переменные (ЛП), учитывая опыт технологов. ЛП оцениваются операторами качественно. Эта информация в результате экспертного опроса формализуется в виде функций принадлежности [17].

\section{Постановка задачи}

Для исследования робастной устойчивости АСР температуры в нижней части СК рассмотрим схему, которая представлена на рис. 3 . 


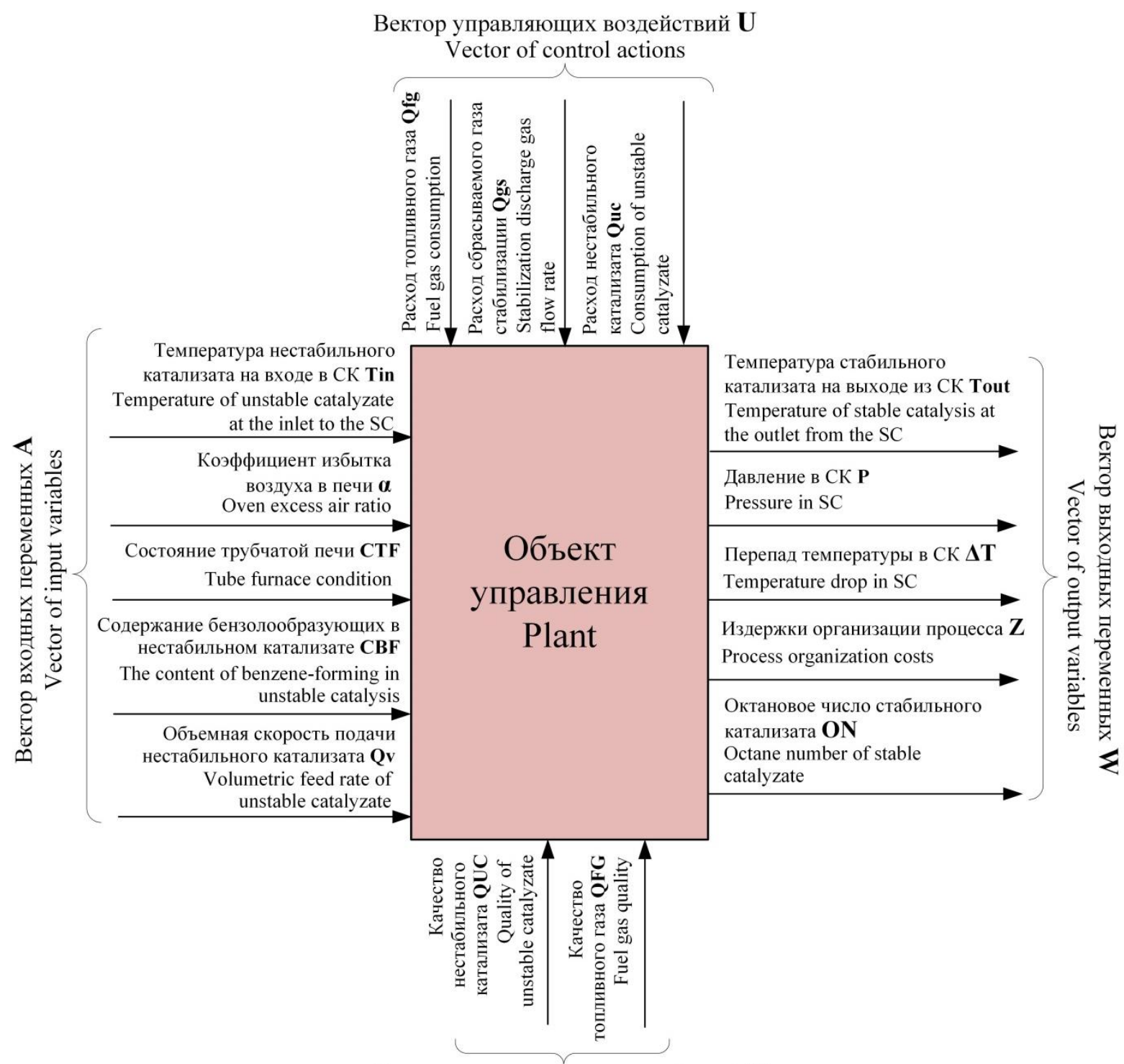

Вектор возмущающих воздействий $\mathbf{V}$

Vector of disturbing influences

Рис. 2. Анализ процесса в блоке стабилизации как объекта управления

Fig. 2. Analysis of the catalyzate stabilization as a control object

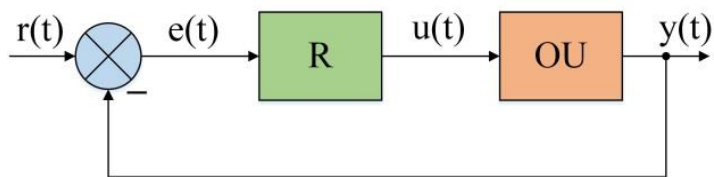

Рис. 3. Типовая схема регулирования

Fig. 3. Typical control scheme

На рис. 3 используются обозначения: $r(t)$ - задающее воздействие; $e(t)$ - ошибка управления; $u(t)-$ управление; $y(t)$ - выход; $R$ - регулятор (ПИДрегулятор); $O U$ - объект управления (процесс в колонне стабилизации) [15]. Регулируемым параметром $y(t)$ является температура в нижней части СК [16]. Заданием $r(t)$ является ступенчатое изменение положения регулирующего устройства, находящегося на трубопроводе нестабильного катализата в колонну стабилизации [17].
На основе экспериментальной переходной кривой для установки КР Л-35-11/1000 получен общий вид полинома знаменателя передаточной функции АСР температуры низа СК (1).

$$
P(s)=a_{0}+a_{1} s+a_{2} s^{2}, a_{i}>0, i=0,1,2 .
$$

Для устойчивости АСР температуры в нижней части СК при воздействии возмущений необходимо определить максимальный размах изменения коэффициентов полинома (1), при котором сохраняется робастная устойчивость, т. е. радиус устойчивости [18]. При изменении коэффициентов полином (1) преобразуется в семейство полиномов (2) знаменателя передаточной функции АСР температуры низа СК.

$$
\begin{gathered}
\wp(s)=\left\{P(s)=a_{0}+a_{1} s+a_{2} s^{2}:\right. \\
\left.\left|a_{i}-a_{i}^{0}\right| \leq \gamma \alpha_{i}, i=0,1,2\right\},
\end{gathered}
$$


где $a_{i}^{0}-$ коэффициенты номинального полинома (1); $\alpha_{i} \geq 0$ - масштабы изменения коэффициентов $a_{i} ; \gamma>0$ размах неопределенности.

Для определения радиуса устойчивости необходимо ввести функции

$$
\begin{gathered}
P_{0}(j \omega)=U_{0}(\omega)+j \omega V_{0}(\omega), \\
U_{0}(\omega)=a_{0}^{0}-a_{2}^{0} \omega^{2}, V_{0}(\omega)=a_{1}^{0}, \\
R(\omega)=\alpha_{0}+\alpha_{2} \omega^{2}, T(\omega)=\alpha_{1}
\end{gathered}
$$

и построить годограф Цыпкина-Поляка [19]

$$
\begin{gathered}
z(j \omega)=x(\omega)+j y(\omega), \\
x(\omega)=\frac{U_{0}(\omega)}{R(\omega)}, y(\omega)=\frac{V_{0}(\omega)}{T(\omega)}, 0 \leq \omega<\infty .
\end{gathered}
$$

Известно [4], что для робастной устойчивости (2) должно выполняться (3)

$$
a_{0}^{0}>\gamma \alpha_{0}, a_{2}^{0}>\gamma \alpha_{2} .
$$

После построения годографа $z(j \omega)$ определяем радиус устойчивости семейства (2)

$$
\gamma_{\max }=\min \left\{\gamma^{*}, \gamma_{0}, \gamma_{2}\right\}, \gamma_{0}=a_{0}^{0} / \alpha_{0}, \gamma_{2}=a_{2}^{0} / \alpha_{2},
$$

где $\gamma^{*}$ - наибольший размер квадрата $\left\{|x(\omega)| \leq \gamma^{*}\right.$, $\left.|y(\omega)| \leq \gamma^{*}\right\}$, который вписан в $z(j \omega)$.

Последние равенства вытекают из условия (3).

\section{Робастная устойчивость АСР температуры в нижней} части СК

На основе экспериментальной переходной кривой для установки КР Л-35-11/1000 получим номинальный полином знаменателя передаточной функции АСР температуры в нижней части СК (4)

$$
P_{0}(s)=1+13,53 s+81,06 s^{2}
$$

с коэффициентами $a^{0}=(1 ; 13,53 ; 81,06)$ и размахом коэффициентов $\alpha=(0,1 ; 1 ; 10)$.

Необходимо определить, возможна ли робастная устойчивость семейства полиномов (2) с номинальным полиномом (4).

Сначала проверим, существует ли $\gamma>0$, обеспечивающее выполнение неравенства (3) - это нужно сделать в первую очередь, поскольку и коэффициенты номинального полинома и их размах заданы:

$$
\begin{gathered}
1>\gamma \cdot 0,1,81,06>\gamma \cdot 10 \Rightarrow \\
\gamma<10, \gamma<8,106 .
\end{gathered}
$$

Таким образом существует $0<\gamma<8,106$.

Введем величины

$$
U_{0}(\omega)=a_{0}^{0}-a_{2}^{0} \omega^{2}=1-81,06 \omega^{2},
$$

$$
\begin{gathered}
V_{0}(\omega)=a_{1}^{0}=13,53, \\
R(\omega)=\alpha_{0}+\alpha_{2} \omega^{2}=0,1+10 \omega^{2}, \\
T(\omega)=\alpha_{1}=1
\end{gathered}
$$

и построим годограф номинального полинома

$$
\begin{array}{r}
P_{0}(j \omega)=U_{0}(\omega)+j \omega V_{0}(\omega)= \\
\quad=1-81,06 \omega^{2}+j 13,53 \omega
\end{array}
$$

и годограф Цыпкина-Поляка

$$
\begin{aligned}
& z(j \omega)=x(\omega)+j y(\omega)=\frac{U_{0}(\omega)}{R(\omega)}+ \\
& +j \frac{V_{0}(\omega)}{T(\omega)}=\frac{1-81,06 \omega^{2}}{0,1+10 \omega^{2}}+j 13,53 .
\end{aligned}
$$

Найдем точки пересечения с осями:

$$
\begin{gathered}
\omega=0: P_{0}(0)=1, z(0)=10+j 13,53, \\
\operatorname{Re}\left(P_{0}(j \omega)\right)=0, \operatorname{Re}(z(j \omega))=0 \Rightarrow \\
\omega \approx 0,111: P_{0}(0,111)=j 1,503, z(0,111)=j 13,53, \\
\operatorname{Im}\left(P_{0}(j \omega)\right)=0 \Rightarrow \omega=0, \operatorname{Im}(z(j \omega))=0 \Rightarrow \omega=\varnothing, \\
\omega \rightarrow \infty: P_{0}(\infty)=-\infty+j \infty, z(\infty)=-8,106+j 13,53 .
\end{gathered}
$$

Результаты моделирования представлены на рис. 4, 5.

Из рис. 5 видно, что существует квадрат со сторонами, равными $\gamma \epsilon(0 ; 8,106)$, вписанный в годограф $z(j \omega)$, значит, семейство полиномов обладает робастной устойчивостью.

Определяем радиус устойчивости интервального семейства:

$$
\begin{gathered}
\gamma_{\min }=\min \left\{\gamma^{*} ; \gamma_{0} ; \gamma_{2}\right\}= \\
=\min \{13,53 ; 8,106 ; 10\}=8,106,
\end{gathered}
$$

где $\gamma^{*}=13,53 ; \gamma_{0}=a_{0}{ }^{0} / \alpha_{0}=8,106, \gamma_{2}=a_{2}{ }^{0} / \alpha_{2}=10$.

Отметим существенное отличие годографов Цыпкина-Поляка и Михайлова. Это объясняется наличием одинаковых степеней знаменателя и числителя дробно-рациональных функций $x(\omega), y(\omega)$ [20].

\section{Заключение}

Таким образом, на основе построения годографа Цыпкина-Поляка рассмотренное семейство полиномов знаменателя передаточной функции АСР температуры в нижней части СК обладает робастной устойчивостью с радиусом устойчивости, равным 8,106. Данный результат используется при разработке АСР температуры в нижней части СК и выборе настроек регуляторов. 


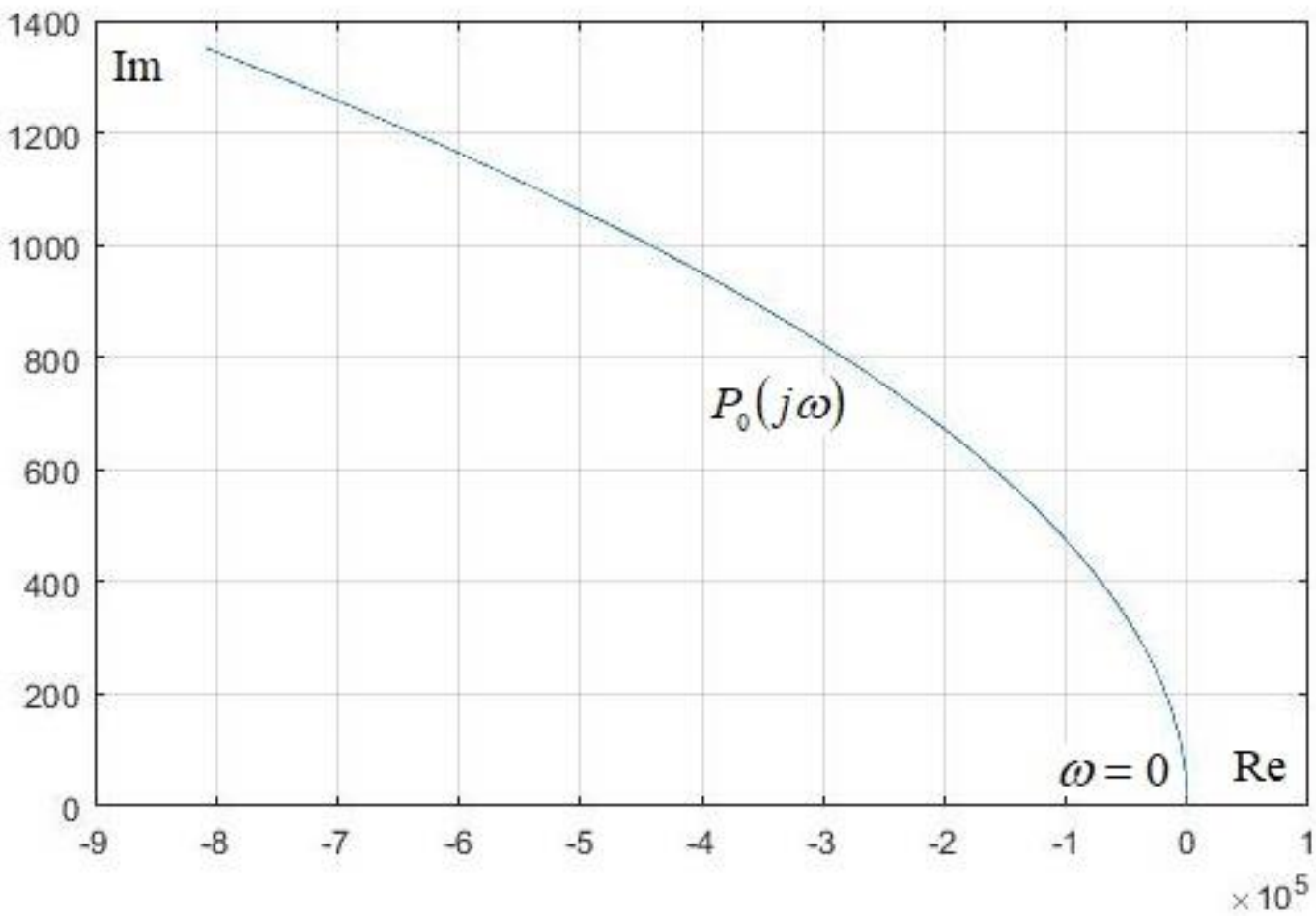

Pис. 3. Годограф номинального полинома

Fig. 3. Nominal polynomial hodograph

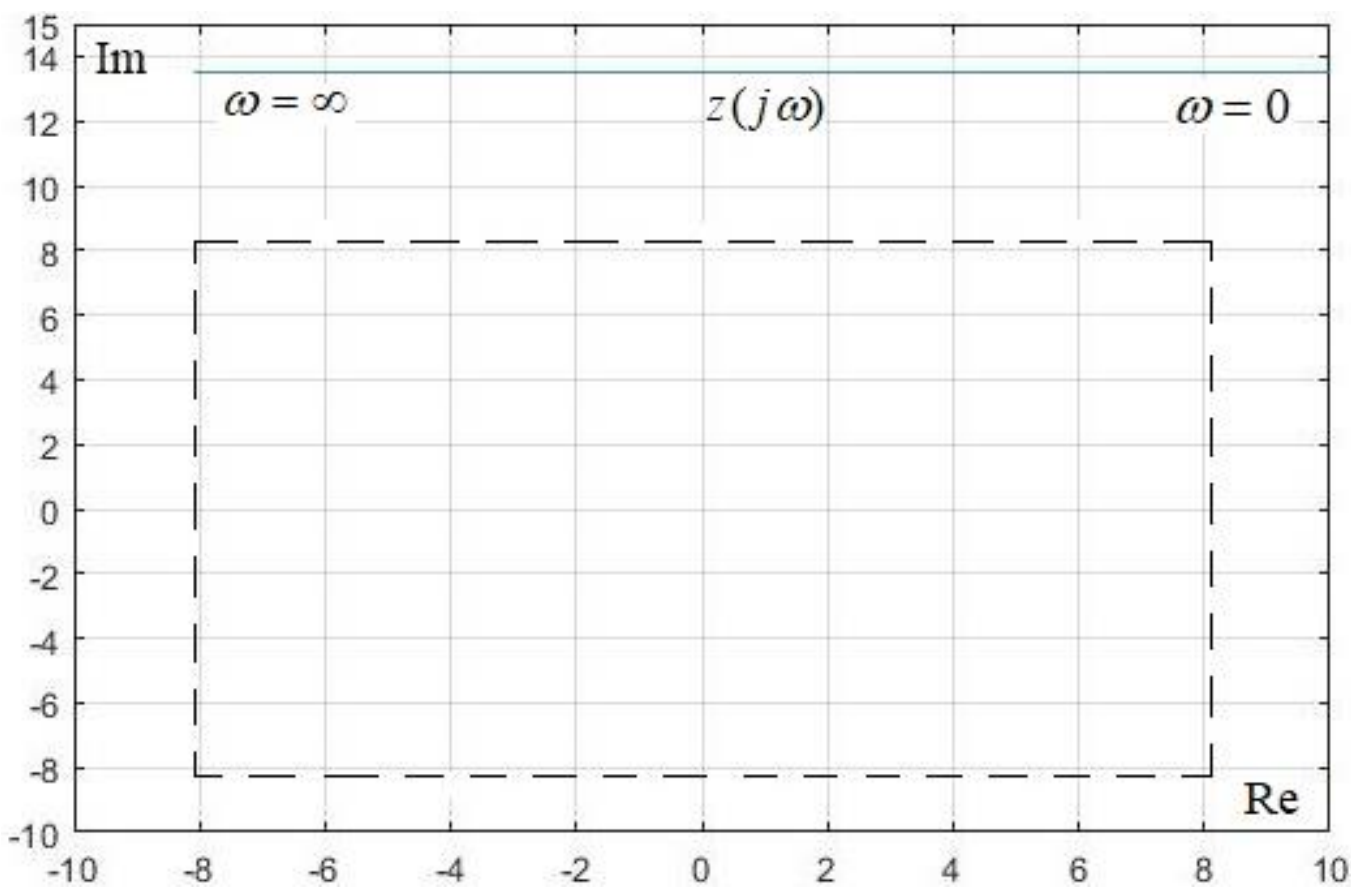

Рис. 4. Годограф Цыпкина-Поляка

Fig. 4. Tsypkin-Polyak hodograph

\section{СПИСОК ЛИТЕРАТУРЫ}

1. Джамбеков А.М., Щербатов И.А. Локальный ПИД-регулятор стабилизации катализата // Современные технологии. Системный анализ. Моделирование. - 2016. - № 3 (51). - С. 98-104.

2. Исследование процесса каталитического риформинга бензиновых фракций казахстанских нефтей и газоконденсатов Ж.А. Карабаев, М.М. Есиркепова, О.Н. Нургали, А.К. Булегенов, О.М. Калмырза // Современные научные исследования и инновации. - 2019. - № 1 (93). - С. 12.
3. Альмохсен М.А. Современные технологии каталитического риформинга // Аллея науки. - 2019. - Т. 3. - № 5 (32). C. $130-132$.

4. Pinheiro C.I.C., Fernandes J.L., Domingues L. Catalytic cracking (FCC) process modeling, simulation and control // Industrial I Engineering Chemistry Research. - 2012. - № 51 (1). - P. 1-29.

5. Gumen M.I. Increasing of the efficiency of the reforming LG-3511/300 // Petroleum Processing and Petrochemistry. - 2001. № 11. - P. 54-57. 
6. Weekman V.A. Model of catalytic cracking conversion in fixed, moving and fluid-bed reactors // Industrial and Engineering Chemistry Process Design and Development. - 1968. - № 7 (1). P. 90-95.

7. Ефремов В.В., Шелудько А.Г. Расчёт робастно-устойчивости автоматической системы регулирования температуры водообогреваемой спецодежды водолаза // Дизайн и технологии. 2013. - № 34 (76). - С. 75-79.

8. Шариков Ю.В., Ткачев И.В., Снегирев Н.В. Моделирование оптимального управления нелинейным объектом // Теоретические основы химической технологии. - 2020. - Т. 54. № 5. - C. 572-583.

9. Математическое моделирование каталитических процессов переработки углеводородного сырья / А.В. Кравцов, Э.Д. Иванчина, Е.Н. Ивашкина, А.В. Костенко, Е.М. Юрьев, В.С. Бесков // Катализ в промышленности. - 2008. - № 6. C. $41-46$.

10. Mircea C., Agachi S., Marimoiu V. Simulation and model predictive control of a UOP fluid catalytic cracking // Chemical Engineering and Processing. -2003 . - V. 42. $-67 \mathrm{p}$

11. Ancheyta J. Modeling and simulation of catalytic reactors for petroleum refining. - Hoboken: Wiley, 2011. $-528 \mathrm{p}$.

12. Smith J.M. Chemical engineering kinetics. - St. Louis: McGrawHill, 1981. $-676 \mathrm{p}$.

13. Управление инновационным развитием наукоемкой производственной системы / В.Г. Матвейкин, Б.С. Дмитриевский, О.В. Дмитриева, В.Р. Разиева, М.В. Сивова // Вопросы современной науки и практики. - 2016. - № 3 (61). - С. 146-152.
14. Литовка Ю.В., Као В.З. Моделирование и оптимизация гальванической ванны с дополнительными катодами // Вестник Тамбовского государственного технического университета. 2016. - T. 22. - № 1. - С. 68-74.

15. Задача управления процессом каталитического риформинга и метод ее решения / В.Г. Матвейкин, Б.С. Дмитриевский, А.Г. Кокуев, А.М. Джамбеков // Известия Томского политехнического университета. Инжиниринг георесурсов. - 2019. T. 330. - № 6. - C. 59-67.

16. Антонов О.В., Проталинский О.М. Построение комбинированных математических моделей технологических процессов // Известия высших учебных заведений. Северо-Кавказский регион. Серия: Естественные науки. - 2003. - № 4. - С. 4-7.

17. Проталинский О.М. Применение методов искусственного интеллекта при автоматизации технологических процессов: монография. - Астрахань: Изд-во Астрах. гос. техн. ун-та, 2004. $-183 \mathrm{c}$.

18. Поляк Б.Т., Щербаков П.С. Робастная устойчивость и управление. - М.: Наука, 2002. - 303 с.

19. Nguang S.K. Robust stabilization of a class of time-delay nonlinear systems // IEEE Transactions on Automatic Control. 2000. - V. 45. - № 4. - P. 756-762.

20. Wu L., Zhou W. Delay-dependent robust stabilization for uncertain singular systems with discrete and distributed delays // Journal of Control Theory and Applications. - 2008. - № 6. P. 171-176.

Поступила 03.05.2021 2.

\section{Информация об авторах}

Джамбеков A.M., кандидат технических наук, преподаватель отделения связи и телекоммуникаций Факультета среднего профессионального образования Астраханского государственного технического университета.

Дмитриевский Б.C., доктор технических наук, профессор, профессор кафедры информационных процессов и управления Института автоматики и информационных технологий Тамбовского государственного технического университета. 
UDC 681.5.037

\title{
SIMULATION OF AN AUTOMATIC TEMPERATURE CONTROL SYSTEM FOR THE STABILIZATION CATALYSATE PROCESS IN CONDITIONS OF UNCERTAINTY
}

\author{
Azamat M. Dzhambekov'1, \\ dzhambekovam@yandex.ru \\ Boris S. Dmitrievsky², \\ dmiboris@yandex.ru \\ 1 Astrakhan State Technical University, \\ 16, Tatishchev street, Astrakhan, 414056, Russia. \\ 2 Tambov State Technical University, \\ 106, Sovetskaya street, Tambov, 392000, Russia.
}

The relevance of the work is caused by the necessity to take into account the influence of disturbances (changes in the quality of the unstable catalysate, the quality of the fuel gas) on temperature control in the lower part of the stabilization column of the catalysate stabilization unit of the catalytic reforming unit. The temperature of the bottom of the stabilization column is an important characteristic of the catalysate stabilization unit, which indicators characterize the quality of functioning of the entire reforming complex. The peculiarity of the control object under consideration consists in the qualitative information contained in the input values and disturbing influences, which include the state of the tubular furnace, the content of benzene-forming substances in the unstable catalysate, the quality of the unstable catalysate, and the quality of the fuel gas. This information is evaluated by operators based on the experience of technologists, taken into account in the form of linguistic parameters based on the results of a survey of experts and represented by membership functions. The influence of perturbations is proposed to be considered in terms of the parameters of the transfer function of the control system based on robust stability methods. It is assumed that these coefficients change over time under the influence of perturbations. At the same time, the task of studying the robust stability under temperature control is important.

Objective: to provide a stable temperature control regime for stabilization column under conditions of uncertainty.

Object: unit for catalysate stabilization of a catalytic reforming unit with continuous catalyst regeneration.

Methods: theory of catalytic reforming, modeling, automatic control theory, systems analysis, computational mathematics.

Results. The paper posed and solved the problem of studying the stability of the temperature control of the stabilization column under conditions of uncertainty. The characteristic of the scheme of catalysate stabilization is given. The control object is analyzed, the variables are distributed into groups as vectors, and the features of the control object are marked. The robust stability is investigated, the simulation results are presented, and the stability radius is determined, which makes it possible to ensure a stable operation of the automatic temperature control system of the lower part of the column under uncertainty.

\section{Key words:}

Catalytic reforming, column bottom temperature, regulation, transfer function, robust stability, nominal polynomial, family of polynomials.

\section{REFERENCES}

1. Dzhambekov A.M., Shcherbatov I.A. Local PID regulator for stabilization of catalysis. Modern Technologies. System Analysis. Modeling, 2016, no. 3 (51), pp. 98-104. In Rus.

2. Karabaev Zh.A., Esirkepova M.M., Nurgali O.N., Bulegenov A.K Kalmyrza O.M. Issledovanie protsessa kataliticheskogo riforminga benzinovykh fraktsy kazakhstanskikh neftey i gazokondensatov [Investigation of catalytic reforming of gasoline fractions of Kazakhstani oils and gas condensates]. Sovremennye nauchnye issledovaniya i innovatsii, 2019, no. 1 (93), p. 12

3. Almokhsen M.A. Modern technologies of catalytic reforming Science Alley, 2019, vol. 3, no. 5 (32), pp. 130-132. In Rus.

4. Pinheiro C.I.C., Fernandes J.L., Domingues L. Catalytic cracking (FCC) process modeling, simulation and control. Industrial I Engineering Chemistry Research, 2012, no. 51 (1), pp. 1-29.

5. Gumen M.I. Increasing of the efficiency of the reforming LG-35-11/300. Petroleum Processing and Petrochemistry, 2001, no. 11 , pp. $54-57$.

6. Weekman V.A. Model of catalytic cracking conversion in fixed, moving and fluid-bed reactors. Industrial and Engineering Chemistry Process Design and Development, 1968, no. 7 (1), pp. 90-95.

7. Efremov V.V., Sheludko A.G. Raschet robastno-ustoychivosti avtomaticheskoy sistemy regulirovaniya temperatury vodoobogrevayemoy spetsodezhdy vodolaza [Calculation of the robustness of an automatic system for regulating the temperature of a water-heated overalls for a diver]. Dizayn i tekhnologii, 2013, no. 34 (76), pp. 75-79.
8. Sharikov Yu.V., Tkachev I.V., Snegirev N.V. Modelirovanie optimalnogo upravleniya nelineynym obyektom [Modeling optimal control of a nonlinear object]. Teoreticheskie osnovy khimicheskoy tekhnologii, 2020, vol. 54, no. 5, pp. 572-583.

9. Kravtsov A.V., Ivanchina E.D., Ivashkina E.N., Kostenko A.V., Yuriev E.M., Beskov V.S. Matematicheskoe modelirovanie kataliticheskikh protsessov pererabotki uglevodorodnogo syrya [Mathematical modeling of catalytic processes for processing hydrocarbon raw materials]. Kataliz v promyshlennosti, 2008, no. 6 , pp. $41-46$.

10. Mircea C., Agachi S., Marimoiu V. Simulation and model predictive control of a UOP fluid catalytic cracking. Chemical Engineering and Processing, 2003, vol. 42, $67 \mathrm{p}$.

11. Ancheyta J. Modeling and simulation of catalytic reactors for petroleum refining. Hoboken, Wiley, 2011. 528 p.

12. Smith J.M. Chemical engineering kinetics. St. Louis, McGraw-Hill, 1981. $676 \mathrm{p}$

13. Matveykin V.G., Dmitrievsky B.S., Dmitrieva O.V., Razieva V.R., Sivova M.V. Upravlenie innovatsionnym razvitiem naukoemkoy proizvodstvennoy sistemy [Management of innovative development of a science-intensive production system]. Voprosy sovremennoy nauki i praktiki, 2016, no. 3 (61), pp. 146-152.

14. Litovka Yu.V., Kao V.Z. Modeling and optimization of a galvanic bath with additional cathodes. Bulletin of the Tambov State Technical University, 2016, vol. 22, no. 1, pp. 68-74. In Rus.

15. Matveykin V.G., Dmitrievsky B.S., Kokuev A.G., Dzhambekov A.M. The task of managing the process of catalytic reforming and the method for its solution. Bulletin of the Tomsk Polytechnic University. Geo Assets Engineering, 2019, vol. 330, no. 6, pp. 59-67. In Rus. 
16. Antonov O.V., Protalinsky O.M. Construction of combined mathematical models of technological processes. News of Higher Educational Institutions. North Caucasian Region. Series: Natural Sciences, 2003, no. 4, p. 4-7. In Rus.

17. Protalinsky O.M. Primenenie metodov iskusstvennogo intellekta pri avtomatizatsii tekhnologicheskikh protsessov: monografiya [The use of artificial intelligence methods in the automation of technological processes: monograph]. Astrakhan, Astrakhan State Technical University Publ. house, 2004. 183 p.

18. Polyak B.T., Shcherbakov P.S. Robastnaya ustoychivost $i$ upravlenie [Robust stability and control]. Moscow, Nauka Publ., 2002. $303 \mathrm{p}$.

\section{Information about the authors}

Azamat M. Dzhambekov, Cand. Sc., teacher, Astrakhan State Technical University. Boris S. Dmitrievsky, Dr. Sc., professor, Tambov State Technical University.
19. Nguang S.K. Robust stabilization of a class of time-delay nonlinear systems. IEEE Transactions on Automatic Control, 2000, vol. 45 , no. 4, pp. 756-762.

20. Wu L., Zhou W. Delay-dependent robust stabilization for uncertain singular systems with discrete and distributed delays. Journal of Control Theory and Applications, 2008, no. 6, pp. 171-176.

Received: 3 May 2021. 